\title{
Difficulties and Countermeasures in Oral Chinese Teaching for Foreigners
}

\author{
Lili Fan \\ International Education College \\ Heihe University \\ Heihe, Heilongjiang, China 164300
}

\author{
Zhichun Zhu \\ International Education College \\ Heihe University \\ Heihe, Heilongjiang, China 164300
}

\begin{abstract}
The paper analyzes the tasks undertaken by oral class of Chinese as a foreign language and problems existing in it. Some oral classes still focus on teaching language points instead of training of language skills. The teaching progress conflicts with practice time. In teaching practice, course teachers carry out collective preparation of instruction and coordinate with teaching tasks of vocabulary and grammar. It helps to improve effectiveness of oral classes through walking out of the classroom and making the best of language environment in school and the society.
\end{abstract}

Keywords-Chinese as a foreign language; spoken language; teaching method; oral expression ability; language skills training

\section{INTRODUCTION}

The main objective described by Chinese Language Proficiency Scales for Speakers of Other Languages is that language use appears in forms of various activities or tasks. The kind of language activities includes receptive mode (listening, reading), output mode (speaking, writing), and interactive type (dialogue and exchange of letters) and intermediary type (interpretation, written translation). According to the description, we can know that oral Chinese teaching for foreigners pays attention to communicative rule and communication strategy, let students comprehensively use language learnt and then acquire language skills and speech communication technique and finally form comprehensive ability of using language. In recent years, more and more overseas students come to China. Most of them are adults, with diversified learning objectives and big individual difference and uneven entry level. Besides, they do not have clear learning objectives. Problems intensively discussed in this article are confusions and thoughts faced by teachers in oral Chinese teaching for foreigners of this group.

\section{LANGUAGE SKILLS AND ORAL CLASS}

At present, in our country, foreign language teaching mode distinguishes language skill classes. Set courses of listening, speaking, reading, and intensive reading and writing respectively according to four skills such as listening, speaking, reading and writing. The teaching of Chinese as a foreign language also follows this mode. Domestic textbooks for teaching Chinese as a foreign language are written according

Fund program: This article is the staged achievement of teaching reform project of higher education in Heilongjiang province, "Research on Bottleneck Problems and Countermeasures of Education for Foreign Students in Local Universities in Heilongjiang”, project number: JG2013010440. to training for different skills. However, new words and grammar points are different even though in supporting teaching materials.

Speaking is a very important language skill. Spoken language skill training includes many aspects: conversational structure, grammar of spoken language, pronunciation, vocabulary, communicative rule and communicative strategy, so the implementation of training is also very complicated. Before we begin to discuss problems faced in oral class, it is necessary to define spoken language. First, we quote a passage of Cai Zhengying: Oral class is language skill class instead of knowledge course. Its teaching content is the ability to use Chinese language instead of knowledge concerning to Chinese language; its teaching method aims at skill practice instead of knowledge teaching. It is special skill course. The purpose is to train oral communicative competence. It attaches importance to training oral communication skills of students. Classroom teaching focuses on training "speaking", but it does not mean that oral class is just for students to speak, because communication cannot be carried out by one person, but need speakers and listeners to complete it together.

Oral class is a very important type of course, because its purpose is to train students' ability to use Chinese language to carry out oral communication in actual context. In the process of training students' ability in oral communication, teachers and students encounter some common problems.

\section{DIFFICULT PROBLEMS}

Firstly, almost all spoken English teachers face the same embarrassing problem, namely how to settle contradictions existing between progress of teaching materials and using of textbook contents for dialogue practice. Teachers teach according to teaching progress and teaching objectives. After teachers teach new words, text and grammar points, students begin to practice sentence patterns and dialogue. Students will have very short period of time for oral practice. It is impossible for students to practice and consolidate vocabularies and grammar points. The oral class is almost equivalent to intensive reading class.

If most of the time is used for dialogue practice, it is impossible to complete teaching progress. Besides, if teachers do not intensively teach use of vocabularies and grammar points, but directly let students carry out dialogue practice 
without error correction individually, it will cause another drawback - the language of students will be nonstandard. Some teachers once put forward the method that teachers let students preview new words and text, and only teach some new words and grammar points intensively in class. The rest of time is used for students to practice and have dialogue. The method will achieve relatively obvious effects if it is used for shortterm accelerated course and the teaching materials are relatively single. Students will have dialogues and complete training mission according to new words and grammar points learnt by them. However, if it is used for long-term language student, the efficiency will be not so obvious. Long-term language students have to learn many subjects, numerous and complicated teaching materials. Especially the schoolwork of students at middle and higher level is heavier. It is impossible to carry out detailed preparation and practice of oral class.

Secondly, another problem of textbooks for spoken language is that the context is not true enough. Sometimes students reflect that the Chinese heard by them is different from that of on textbooks. For example, the most common form of sentence in textbook is that "Can you use Chinese?" However, most students often hear Chinese people ask "Can you speak Chinese?" After entering middle and advanced class to learn, students will find spoken language used in daily communication cannot be used in formal occasions such as lecture, professional discussion and news interview. Although our textbooks begin to gradually involve themes such as lecture and news, students will feel that they cannot make progress through oral class after entering advanced class. On one hand, they still cannot understand many vocabularies in life; on the other hand, they think the spoken Chinese learnt by them is unpractical in formal occasions.

Thirdly, teaching methods of many Chinese teachers for foreigners are still too traditional. At present, teaching methods frequently used at home and abroad include translation method, audio-lingual method, communicative approach and task-based method. The teaching process of translation method is to explain pronunciation, writing and grammatical rules first, and then give example sentences for translation practice. The explanation of translation method for grammatical rules is very detailed, but the shortcoming is that the training for listening and speaking ability is not enough. The audio-lingual method focuses on pattern drill, seldom explaining grammatical rules. Teachers arrange teaching activities according to the sequence of listening, speaking, reading and writing, laying particular emphasis on pronunciation and oral practice. Audio-lingual method is a teacher-centered passive teaching method. Communicative approach does not require students to memorize mechanically nor expect students to say correct sentences. Instead, students understand communicative function of language through role play, games and situation setting and achieve the purpose of verbal communication. It not only lets students finish communicative task but also lets them understand cultural meaning reflected in language. The basis of task-based method is criterion of course analysis. But using language to learn language occupies a dominant position.

Finally, error correcting problems in language learning are worthy of thinking of all teachers. The process of learning language is a process that errors appear frequently. The learning process without making errors is unimaginable. Although we can accept errors made by students, it is not an easy thing to correct those errors. We shall clearly know what kind of mistakes shall be corrected, how to correct them, so that we will not combat enthusiasm of students in learning language and make language learnt by students become more and more standard.

\section{ThOUGHTS ON THE ABOVE PROBLEMS}

For the first problem, we think firstly, oral class must make the focal points stand out. It is impossible to let students remember all new words and grammar points, especially in intermediate stage and advanced stage. Therefore, in oral class, it is necessary to let students practice error-prone vocabularies and grammars with high difficulty. Secondly, combine intensive reading class with oral class. Teachers teaching intensive reading explain vocabularies and grammar. In oral class, students use knowledge points learnt in intensive reading class to practice spoken Chinese. Teachers can collect some related extracurricular learning materials for students according to contents of intensive reading text, to enlarge quantity of vocabulary of students and help students to consolidate more knowledge learnt by them better and faster. Thirdly, let students cooperate by dividing them into groups to find out difficult points of grammar and vocabulary. It is a student-centered method for independent learning.

Every time before class, we can distribute learning materials to students, divide students into several groups according to will of students or certain rules, let them find out difficult points encountered by them in learning, and then practice intensively in oral class.

For the second problem, we think the existing textbooks for spoken Chinese can be adjusted and improved further. Firstly, vocabularies and sentence patterns with relatively high frequency of utilization shall be selected on the basis of full investigation on corpus.

On setting of dialogue, it is necessary to take trueness of context into full consideration, instead of compiling conversations and texts according to grammar and vocabulary. In a word, teaching materials must highlight characteristics of spoken language. Besides, the compilation of textbooks for spoken Chinese shall gather connected factors into a whole in the form of unit or topic, so that it is convenient for students to memorize. Except for selecting lectures and dialogues used in formal occasions, intermediate and advanced textbooks for spoken Chinese also deeply analyze words and grammar used in special literary forms such as news. Let students realize certain differences of vocabularies and grammars exist between daily communication and formal occasions, so that they can standardize their language more consciously.

Because differences exist in many aspects such as learning time and learning goals, the contents of spoken Chinese that students need to learn are different. It needs cycle to compile, publish and use teaching materials. It decides all textbooks for spoken Chinese will lag behind spoken Chinese in different degrees. 
Therefore, in teaching of spoken Chinese, teachers shall properly increase and decrease according to teaching materials. Besides, teachers shall fully stimulate enthusiasm and initiative of students and let students use knowledge learnt, make investigation and give lectures, use modern chat tools and surf the internet, as well as organize evening party and competition by themselves. Let students contact the truest context and language materials and have the opportunity and interest in strengthening oral practice after class purposefully.

For the third problem, students have different native languages and educational background and learn with companions of different thinking models of language together. The foreign language teaching methods in their own country are different from that of our country. In many countries, the most frequently-used foreign language teaching methods include task-based approach and communicative approach. That is to say, in class, the teacher serves as guider to encourage students to participate in and communicate and dominate their learning. No matter using what kinds of teaching methods and class modes, the purpose is to let students learn well and make progress rapidly. Therefore, according to teaching situation, in order to achieve teaching goals, teachers need to decide more proper teaching methods for students on the basis of characteristics of each class and learning objectives of students.

When adopting different teaching methods, we shall also pay attention to individual difference of students. For students with different characters, we shall adopt different ways of questioning, activities even sequence of presentation. In addition, when students accept different language knowledge, the level of sensitivity of each sense organ is different. Some have very strong logical thinking ability. Some people have very good hearing. Some people are good at expressing. Although in oral practice, we shall also attach importance to different characteristics of students, use various teaching methods to stimulate and enlighten students, let them speak and practice more, and then achieve the goal of improving oral proficiency.

For the last problem, traditional foreign language teaching method and modern foreign language teaching method hold different attitudes toward errors. The first attitude is that errors should be corrected since it appears for the first time; the second attitude is that error is a part of the process of learning foreign language, so we must analyze it seriously.

Traditional foreign language teaching method holds the opinion that habits must be developed in learning a foreign language. Modern foreign language teaching method thinks learning of foreign language is to make hypothesis, assuming that both correct expression and wrong expression shall exist in scene. Therefore, it is necessary to correct errors that interfere with communication. It is not always necessary to strictly correct errors that the language is not fluent or not accurate. Fluent language does not mean there isn't any error at all. However, language practice at primary level requires the language must be very normative.

The correction in oral class is an embarrassing problem for teachers and students. Teachers shall fully understand life and educational background of students. In lively and humorous classroom climate, combine error correction with encouragement. Respect character difference of students as individuals and let students keep the pleasure and confidence in learning in strict error correction.

Except for the above problems, the problem of class capacity is also a very great challenge for spoken language teaching. The higher the capacity, the less opportunity students will have to learn. For long-term students, if the number of students is too little, it goes against discussion and role play of students. Besides, it may lead to excessively one-sided and boring topics. In specific teaching, we think class capacity of six to ten people is convenient for operation of spoken language teaching.

\section{CONCLUSION}

The thesis mainly discusses contradictions between teaching progress and oral practice, and problems that the language environment of oral teaching book is not true, the existing teaching method centers on teachers and error correction in oral Chinese teaching for foreigners.

For learning of spoken language, we quote the opinions on cultivation of foreign language learners that teachers need to let students improve the following skills: pronunciation, use of correct syntactic structure and understanding characteristics of communicators, especially common knowledge of communicators and us, status of communicators and relationships between communicators and us. Use appropriate vocabulary, contents of discussion and background information according to communication object and use correct communication strategies. In order to let others have more effective feedback, pay attention to success of communication and interaction and using corresponding vocabulary, grammar and manner of discourse.

\section{REFERENCES}

[1] Liu Xiaoyu. Research Summary on Oral Chinese Teaching for Foreigners [J], Language Teaching and Linguistic Studies, 2001(2).

[2] Xu Jian. Research on Teaching Design of Oral Class of Chinese as a Foreign Language [J], Journal of Inner Mongolia Normal University: Education Science Edition, 2008, 21(9): 122-124. 